University of Nebraska - Lincoln

DigitalCommons@University of Nebraska - Lincoln

\title{
Thermotolerance and rapid cold hardening ameliorate the negative effects of brief exposures to high or low temperatures on fecundity in the flesh fly, Sarcophaga crassipalpis
}

Joseph Rinehart

Ohio State University, Columbus, U.S.A.

George Yocum

USDA-ARS

David Denlinger

USDA-ARS

Follow this and additional works at: https://digitalcommons.unl.edu/entomologyother

Part of the Entomology Commons

Rinehart, Joseph; Yocum, George; and Denlinger, David, "Thermotolerance and rapid cold hardening ameliorate the negative effects of brief exposures to high or low temperatures on fecundity in the flesh fly, Sarcophaga crassipalpis" (2000). Entomology Papers from Other Sources. 68.

https://digitalcommons.unl.edu/entomologyother/68

This Article is brought to you for free and open access by the Entomology Collections, Miscellaneous at DigitalCommons@University of Nebraska - Lincoln. It has been accepted for inclusion in Entomology Papers from Other Sources by an authorized administrator of DigitalCommons@University of Nebraska - Lincoln. 


\title{
Thermotolerance and rapid cold hardening ameliorate the negative effects of brief exposures to high or low temperatures on fecundity in the flesh fly, Sarcophaga crassipalpis
}

\author{
J OSEPH P. RINEHART*, GEORGE D. Y OCUM $†$ and \\ D A V I D L. DE N L I N GER* \\ *Department of Entomology, Ohio State University, Columbus, U.S.A. and †Red River Valley Agricultural Research Center, \\ USDA-ARS, Fargo, ND, U.S.A.
}

\begin{abstract}
Although the immediate effects of temperature stress are well documented, the longer-term effects of such stresses are more poorly known. In these experiments, we investigate the effects of suboptimal and supraoptimal temperatures during pharate adult development on fecundity in the flesh fly, Sarcophaga crassipalpis Macquart. A $1 \mathrm{~h}$ cold shock at $-10^{\circ} \mathrm{C}$ during the red-eye pharate adult stage decreases the fecundity of both sexes. Induction of rapid cold hardening by pre-treatment at $0^{\circ} \mathrm{C}$ for $2 \mathrm{~h}$ partially prevents reproductive impairment. Heat shock of pharate adults for $1 \mathrm{~h}$ at $45^{\circ} \mathrm{C}$ also reduces fecundity in both sexes, but inducing thermotolerance by pre-treatment at $40^{\circ} \mathrm{C}$ for $2 \mathrm{~h}$ affords protection only to females. Males heat shocked at $45^{\circ} \mathrm{C}$ or first pre-treated at $40^{\circ} \mathrm{C}$ consistently fail to transfer sperm to the females. The injury inflicted on males by heat shock is most pronounced when the stress is administered to pharate adults or adults; wandering larvae and true pupae are unaffected. The implications of these data for naturally occurring populations are discussed.
\end{abstract}

Key words. Cold shock, fecundity, heat shock, induced thermotolerance, rapid cold hardening.

\section{Introduction}

Any organism exposed to temperature extremes will realize a variety of detrimental effects. Insects are especially vulnerable to such extremes because of their small size and ectothermic physiology. Damage as a result of high temperature has been particularly well studied (Denlinger \& Yocum, 1998). Lethality can occur immediately, as documented for several insects of economic importance (Armstrong, 1992; Hansen, 1992), or as a result of a failure to complete development at a later stage as observed in Sarcophaga crassipalpis (Denlinger et al., 1991) and Drosophila melanogaster (Mitchell \& Lipps, 1978). Sublethal effects, such as decreased longevity (Chihrane et al., 1993), wing deformation (Milkman, 1962)

Correspondence: David L. Denlinger, Department of Entomology, Ohio State University, 1735 Neil Avenue, Columbus, OH 43210-1220, U.S.A. Tel: +1 614292 8209; fax: +1 6142927865 ; e-mail: denlinger.1@osu.edu and a decrease in fertility (Arbogast, 1981), especially by sterilization of males (Saxena et al., 1992), are also frequently noted in heat-stressed insects. Exposure to low temperatures can be equally detrimental (Denlinger \& Lee, 1998), leading to delayed mortality (Bale et al., 1989), nervous system impairment (Yocum et al., 1994) and reduced fecundity caused by egg mortality (Coulson \& Bale, 1992).

Exposure to suboptimal or supraoptimal temperatures are not always detrimental. When exposed to temperatures that are high enough to induce the heat-shock response, but insufficient to cause substantial damage, thermotolerance can be acquired. This can lead to amelioration of the lethal and sublethal effects of subsequent exposure to high temperatures. Similar to thermotolerance, the induction of rapid cold hardening by exposure to less severe temperatures can protect against the effects of subsequent cold shock, as demonstrated in several insects including the flesh fly S. crassipalpis (Chen et al., 1987; Lee et al., 1987). 
An interesting question concerning the effects of temperature extremes and amelioration by pre-treatment is whether these treatments affect the fecundity of the treated individual. Is an organism that is protected against the lethal effects of an exposure also protected against detrimental effects to its reproductive fitness? To answer this question, we investigated the effects of heat shock and cold shock on the fecundity of the flesh fly $S$. crassipalpis Macquart, and tested whether induced thermotolerance and rapid cold hardening can prevent injury associated with reproduction. We show that both heat shock and cold shock of pharate adults negatively affect the eventual reproductive success of the adults. Additionally, acquired thermotolerance positively affected the fecundity of heatshocked females, but had no effect on the heat sterilization of males. Rapid cold hardening protected the fecundity of both cold-shocked males and females, raising the possibility of its importance to reproductive success in ecologically relevant situations.

\section{Materials and Methods}

Insects

A laboratory colony of $S$. crassipalpis Macquart was used throughout the study. All life stages were reared at $25^{\circ} \mathrm{C}$ in a long-day photocycle (LD 15:9h). All experimental cages consisted of 15 females and 15 males. When mating was observed, recordings were made daily in the morning hours of the light cycle.

\section{Temperature treatments}

Fifteen red-eye pharate adults were placed in $13 \times 100 \mathrm{~mm}$ thin-walled glass tubes that were plugged with cotton wool and

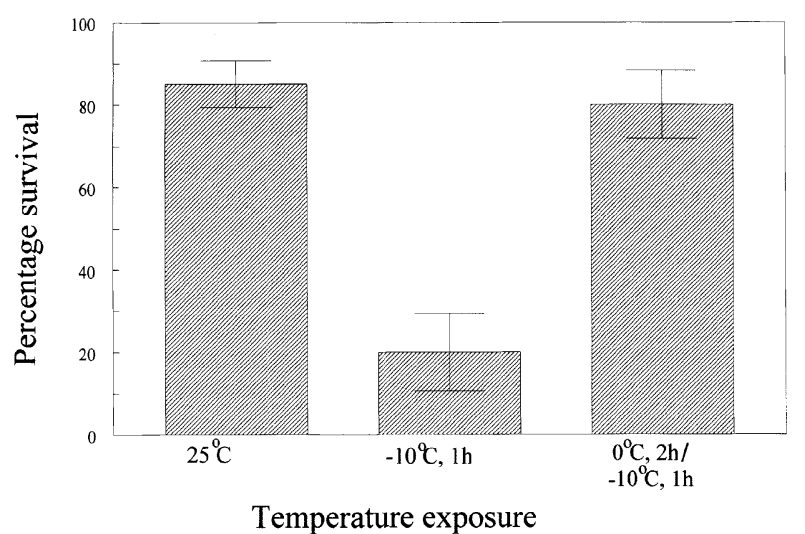

Fig. 1. Effects of cold shock $\left(-10^{\circ} \mathrm{C}\right)$ and rapid cold hardening $(2 \mathrm{~h}$ at $0^{\circ} \mathrm{C}$ before exposure to $-10^{\circ} \mathrm{C}$ ) during pharate adult development on adult mortality monitored 10 days post-emergence. Vertical bars and lines indicate mean $\pm \mathrm{SE}, n=$ three replicates of 30 flies per cage. partly submerged in a Lauda model RMT-20 circulating water bath. Treatment regimes followed those previously determined to elicit damage and induce tolerance. These conditions comprised: heat shock at $45^{\circ} \mathrm{C}$ for $1 \mathrm{~h}$, induced thermotolerance at $40^{\circ} \mathrm{C}$ for $2 \mathrm{~h}$, cold shock at $-10^{\circ} \mathrm{C}$ for $1 \mathrm{~h}$, and rapid cold hardening at $0^{\circ} \mathrm{C}$ for $2 \mathrm{~h}$. All experiments were performed in triplicate unless otherwise stated.

\section{Uterus contents}

The flesh flies are ovoviviparous, and at $25^{\circ} \mathrm{C}$ the eggs are ovulated, fertilized and transported into the uterus on day 5. The first-instar larvae are normally ready to be larviposited at 10 days post-emergence. Flies were raised for 6 days postemergence on a diet of sugar and liver, after which the liver was removed to prevent premature larviposition. At 10 days post-emergence, individual females were anaesthetized by cooling on ice, the posterior abdominal segments were removed with scissors, and the contents of the uterus were extracted by applying pressure to the abdomen in an anterior to posterior direction. The resultant first-instar larvae and eggs were collected in insect saline, and counted under a dissecting microscope. The total number of larvae and eggs was used to determine the total number of eggs produced, and the number of larvae was used to assess egg fertilization.

\section{Spermatheca contents}

Females were maintained in the presence of males for 6 days post-emergence, after which they were anaesthetized by cooling on ice and dissected to assess the contents of the spermatheca. The three spermathecae were located, isolated on a glass slide, and ruptured with an insect pin in a $100 \mu \mathrm{L}$ droplet of saline. A $10 \mu \mathrm{L}$ sample was transferred to a second glass slide, stained with $0.4 \%$ trypan blue, and mounted under a cover slip. The total number of sperm in the sample was counted under a compound microscope; multiplication by the dilution factor gave the total number of sperm per spermatheca.

\section{Results}

Effects of cold shock and rapid cold hardening on adult longevity

Two forms of increased mortality were sustained by coldshocked individuals. First was the previously documented decrease in successful eclosion (Lee \& Denlinger, 1985), responsible for $25 \%$ mortality in treated individuals. In those insects that successfully emerged, a further detrimental effect was realized as decreased adult longevity (see Fig. 1), culminating in a $75 \%$ decrease in survival to day $10\left(\chi^{2}\right.$ $P<0.001$, with 1 degree of freedom).

Rapid cold hardening protected against both types of delayed mortality. Chen et al. (1991) reported that pre- 
treatment of $2 \mathrm{~h}$ at $0^{\circ} \mathrm{C}$ protected against eclosion impairment. Similarly, the decrease in adult longevity was prevented with rapid cold hardening (Fig. 1).

\section{Effects of cold shock on fecundity}

Two parameters were used to assess the effect of cold shock on fecundity: the number of larvae present in the uterus (hence the number of eggs fertilized) and the total number of eggs produced (larvae and unfertilized eggs). Of those individuals that survived for 10 days post-emergence, a $1 \mathrm{~h}$ cold shock at $-10^{\circ} \mathrm{C}$ during pharate adult development (red-eye stage) caused a significant decrease in the number of fertilized eggs collected per female (Mann-Whitney $P<0.001$ ), whereas total egg production was unaffected (Table 1). A $2 \mathrm{~h}$ treatment at $0^{\circ} \mathrm{C}$ had little affect on either parameter. To determine which sex sustained damage, females treated as red-eye pharate adults for $1 \mathrm{~h}$ at $-10^{\circ} \mathrm{C}$ were crossed with males reared at $25^{\circ} \mathrm{C}$ and vice versa, with the results being compared with those of untreated controls (Table 2). When females were treated, a $53 \%$ reduction (Mann-Whitney $P=0.004$ ) in larvae per uterus was observed, whereas the cold shock of males led to a $95 \%$ reduction (Mann-Whitney $P<0.001$ ), indicating that both sexes were affected by cold shock. Additionally, cold shock affected the number of mating pairs observed in treated cages

Table 1. Effects of cold shock $\left(-10^{\circ} \mathrm{C}\right)$ and rapid cold hardening $\left(0^{\circ} \mathrm{C}\right.$ prior to cold shock) on egg fertilization. $n=45$ females per treatment group.

\begin{tabular}{lll}
\hline $\begin{array}{l}\text { Temperature } \\
\text { treatment }\end{array}$ & $\begin{array}{l}\text { No. eggs produced } \\
\text { Mean } \pm \mathrm{SE}\end{array}$ & $\begin{array}{l}\text { Percentage fertilized } \\
\text { Mean } \pm \mathrm{SE}\end{array}$ \\
\hline $25^{\circ} \mathrm{C}$ & $71.0 \pm 3.3$ & $74.8 \pm 5.3$ \\
$0^{\circ} \mathrm{C}, 2 \mathrm{~h}$ & $68.0 \pm 3.5$ & $72.5 \pm 4.4$ \\
$-10^{\circ} \mathrm{C}, 1 \mathrm{~h}$ & $67.0 \pm 2.8$ & $8.4 \pm 3.0$ \\
$0^{\circ} \mathrm{C}, 2 \mathrm{~h} /-10^{\circ} \mathrm{C}, 1 \mathrm{~h}$ & $67.0 \pm 2.5$ & $42.2 \pm 3.7$ \\
\hline
\end{tabular}

(Table 2). Cold shock of females led to a $25 \%$ reduction in the number of mating pairs observed through 10 days postemergence, whereas the cold shock of males yielded only a single mating pair, as observed when both sexes were treated.

\section{Effects of rapid cold hardening on fecundity}

Table 1 shows that induction of rapid cold hardening $\left(0^{\circ} \mathrm{C}\right.$ for $2 \mathrm{~h}$ before placement at $-10^{\circ} \mathrm{C}$ for $1 \mathrm{~h}$ ) in both sexes increased the number of fertilized eggs to a level above that observed after cold shock alone (Mann-Whitney $P=0.005$ ), although this value still remained significantly lower than for controls maintained at $25^{\circ} \mathrm{C}$ (Mann-Whitney $P=0.025$ ). When males cold-hardened prior to cold shock were mated with normal females (held continuously at $25^{\circ} \mathrm{C}$ ) or when coldhardened females were mated with normal males, fertility was fully protected (Table 2).

\section{Effects of heat shock on fecundity}

Heat shock of both sexes at $45^{\circ} \mathrm{C}$ for $1 \mathrm{~h}$ severely affected fecundity; the number of eggs produced was significantly reduced to $90 \%$ of that for untreated flies (Mann-Whitney $P=0.020)$ and more importantly, none of the eggs were fertilized (Table 3). A treatment of $2 \mathrm{~h}$ at $40^{\circ} \mathrm{C}$ had no affect on either parameter. Males exposed to $45^{\circ} \mathrm{C}$ and crossed with normal females failed to fertilize the eggs (Table 4), whereas total egg production was unaffected (Mann-Whitney $P=0.245)$. Females exposed to $45^{\circ} \mathrm{C}$ and mated with untreated males showed a $15 \%$ reduction in total egg production (MannWhitney $P=0.042$ ), whereas the percentage of eggs fertilized did not change substantially (Table 4 ). These data suggest that each effect is realized by the heat shock of one sex: heat shock of males caused complete reduction in fertility, whereas the heat shock of females reduced egg production. We were unable to detect any alteration in incidence of mating in response to high temperature treatment (data not shown).

Table 2. Effects of cold shock $\left(-10^{\circ} \mathrm{C}\right)$ and rapid cold hardening $\left(2 \mathrm{~h}\right.$ at $\left.0^{\circ} \mathrm{C}\right)$ on fecundity as a function of sex treated. $n=45$ females per treatment group.

\begin{tabular}{lllll}
\hline Sex treated & $\begin{array}{l}\text { Temperature } \\
\text { treatment }\end{array}$ & $\begin{array}{l}\text { No. eggs produced } \\
\text { Mean } \pm \mathrm{SE}\end{array}$ & $\begin{array}{l}\text { Percentage fertilized } \\
\text { Mean } \pm \mathrm{SE}\end{array}$ & $\begin{array}{l}\text { Observed mating pairs } \\
\text { Mean } \pm \mathrm{SE}\end{array}$ \\
\hline Both & $25^{\circ} \mathrm{C}$ & $75.2 \pm 1.6$ & $87.9 \pm 4.4$ & $27 \pm 9.6$ \\
Females & $-10^{\circ} \mathrm{C}, 1 \mathrm{~h}$ & $65.4 \pm 1.7$ & $47.7 \pm 6.4$ & $20 \pm 4.5$ \\
Males & $-10^{\circ} \mathrm{C}, 1 \mathrm{~h}$ & $74.9 \pm 1.4$ & $4.7 \pm 2.8$ & $1 \pm 0.6$ \\
Both & $-10^{\circ} \mathrm{C}, 1 \mathrm{~h}$ & $75.1 \pm 2.2$ & $1.5 \pm 1.2$ & \\
Males & $25^{\circ} \mathrm{C}$ & $69.1 \pm 1.3$ & $82.4 \pm 2.2$ & \\
Males & $0^{\circ} \mathrm{C}, 2 \mathrm{~h}$ & $71.9 \pm 1.5$ & $92.2 \pm 2.8$ & \\
Males & $-10^{\circ} \mathrm{C}, 1 \mathrm{~h}$ & $72.2 \pm 1.8$ & $7.8 \pm 2.8$ & \\
Males & $0^{\circ} \mathrm{C}, 2 \mathrm{~h} /-10^{\circ} \mathrm{C}, 1 \mathrm{~h}$ & $69.5 \pm 1.5$ & $90.1 \pm 2.2$ & \\
Females & $25^{\circ} \mathrm{C}$ & $73.8 \pm 1.1$ & $78.5 \pm 3.9$ & \\
Females & $0^{\circ} \mathrm{C}, 2 \mathrm{~h}$ & $74.4 \pm 1.2$ & $90.1 \pm 3.1$ & \\
Females & $-10^{\circ} \mathrm{C}, 1 \mathrm{~h}$ & $71.6 \pm 1.5$ & $64.0 \pm 5.2$ & \\
Females & $0^{\circ} \mathrm{C}, 2 \mathrm{~h} /-10^{\circ} \mathrm{C}, 1 \mathrm{~h}$ & $78.3 \pm 1.2$ & $86.0 \pm 3.1$ & \\
\hline
\end{tabular}




\section{Heat shock of different durations}

The treatment of both sexes at $45^{\circ} \mathrm{C}$ administered in increments of $15 \mathrm{~min}$ showed that the cessation of egg fertilization and the reduction of total egg production were manifested as a result of different durations of heat shock (Table 5). For egg fertilization, a 15-min treatment had no significant effect, whereas $30 \mathrm{~min}$ or more of heat shock caused a complete loss of fertility (Mann-Whitney $P<0.001$ ). The effect on total egg production required longer exposure, with a significant reduction observed only after $60 \mathrm{~min}$ at $45^{\circ} \mathrm{C}$ (Mann-Whitney $P=0.016$ ).

\section{Heat shock at different life stages}

To determine whether the observed effects of heat shock were exclusive to the pharate adult stage, other life stages were treated at $45^{\circ} \mathrm{C}$ for $30 \mathrm{~min}$, the shortest amount of time needed to eliminate fertilization when treating pharate adults. When compared with untreated controls, the heat shock of thirdinstar wandering larvae, and true pupae (4 days after pupariation) had no significant effect on fertility, whereas the heat shock of both red-eye pharate adults, and 1 day post-emergent adults prevented fertilization (Table 6).

\section{Effects of thermotolerance on fecundity}

Induction of thermotolerance by treatment for $2 \mathrm{~h}$ at $40^{\circ} \mathrm{C}$ directly before the $1 \mathrm{~h}$ at $45^{\circ} \mathrm{C}$ heat shock resulted in partial

Table 3. Fecundity observed when both males and females were heat shocked at $45^{\circ} \mathrm{C}$ or exposed to conditions that promote thermotolerance $\left(40^{\circ} \mathrm{C}\right) . n=45$ females per treatment group.

\begin{tabular}{lll}
\hline $\begin{array}{l}\text { Temperature } \\
\text { treatment }\end{array}$ & $\begin{array}{l}\text { No. eggs produced } \\
\text { Mean } \pm \mathrm{SE}\end{array}$ & $\begin{array}{l}\text { Percentage fertilized } \\
\text { Mean } \pm \text { SE }\end{array}$ \\
\hline $25^{\circ} \mathrm{C}$ & $81.4 \pm 2.5$ & $85.4 \pm 3.7$ \\
$40^{\circ} \mathrm{C}, 2 \mathrm{~h}$ & $88.9 \pm 1.3$ & $83.5 \pm 1.7$ \\
$45^{\circ} \mathrm{C}, 1 \mathrm{~h}$ & $74.9 \pm 2.8$ & $0.0 \pm 0.0$ \\
$40^{\circ} \mathrm{C}, 2 \mathrm{~h} / 45^{\circ} \mathrm{C}, 1 \mathrm{~h}$ & $83.9 \pm 2.6$ & $0.0 \pm 0.0$ \\
\hline
\end{tabular}

protection of fecundity (Table 3 ). When both sexes were pretreated, total egg production was protected by induced thermotolerance, whereas egg fertilization was unaffected: no larvae were present in the uteri after heat shock both with and without pre-treatment. Thermotolerant males (pre-treated $2 \mathrm{~h}$ at $40^{\circ} \mathrm{C}$ ) mated with untreated females received no protection, whereas pre-treated females paired with untreated males showed a partial restoration of egg production (Table 4), with females treated at $45^{\circ} \mathrm{C}$ alone exhibiting $86 \%$ of the egg production of controls, and pre-treated females $\left(2 \mathrm{~h}\right.$ at $40^{\circ} \mathrm{C}$ before exposure to $45^{\circ} \mathrm{C}$ ) showing $93 \%$ of controls levels. Of additional interest is the observation that the protective effects of the pre-treatment were still evident when a 4-h incubation at $25^{\circ} \mathrm{C}$ was inserted between the pre-treatment and the heat shock (Table 4).

Effect of heat shock/thermotolerance on presence of sperm in the spermatheca

Previous studies have shown that a major effect of heat shock on male fecundity is direct injury to the sperm (Saxena et al., 1992). Thus, we might expect the aforementioned effects on male fertility to be further demonstrated by reduced sperm viability or the inability to transfer sperm to the female. To test the latter hypothesis, we observed the contents of the spermatheca of untreated females mated with males maintained at $25^{\circ} \mathrm{C}$, treated at $40^{\circ} \mathrm{C}$ for $2 \mathrm{~h}, 45^{\circ} \mathrm{C}$ for $1 \mathrm{~h}$, and pretreated at $40^{\circ} \mathrm{C}$ for $2 \mathrm{~h}$ followed by a heat shock of $45^{\circ} \mathrm{C}$ for $1 \mathrm{~h}$. Although the $40^{\circ} \mathrm{C}$ incubation had no effect on the number of sperm recovered from the spermatheca, no sperm were present in the spermatheca of females mated with heat-shocked males or those that were pre-treated (Table 7).

\section{Discussion}

A brief cold shock of red-eye pharate adults leads to diminished fitness at three points during development: reduction in the number of individuals surviving to adulthood, reduction of adult longevity, and reduction of the reproductive potential of the survivors. All three of these parameters

Table 4. Effects of heat shock $\left(45^{\circ} \mathrm{C}\right)$ and thermotolerance $\left(2 \mathrm{~h}\right.$ at $\left.40^{\circ} \mathrm{C}\right)$ on fecundity as a function of sex treated. $n=45$ females per treatment group.

\begin{tabular}{llll}
\hline Sex treated & $\begin{array}{l}\text { Temperature } \\
\text { treatment }\end{array}$ & $\begin{array}{l}\text { No. eggs produced } \\
\text { Mean } \pm \mathrm{SE}\end{array}$ & $\begin{array}{l}\text { Percentage fertilized } \\
\text { Mean } \pm \mathrm{SE}\end{array}$ \\
\hline Males & $25^{\circ} \mathrm{C}$ & $77.1 \pm 1.6$ & $78.7 \pm 7.9$ \\
Males & $40^{\circ} \mathrm{C}, 2 \mathrm{~h}$ & $79.7 \pm 2.3$ & $80.7 \pm 4.8$ \\
Males & $45^{\circ} \mathrm{C}, 1 \mathrm{~h}$ & $73.7 \pm 1.6$ & $0.0 \pm 0.0$ \\
Males & $40^{\circ} \mathrm{C}, 2 \mathrm{~h} / 45^{\circ} \mathrm{C}, 1 \mathrm{~h}$ & $73.9 \pm 2.1$ & $0.0 \pm 0.0$ \\
Females & $25^{\circ} \mathrm{C}$ & $78.7 \pm 3.7$ & $93.4 \pm 4.7$ \\
Females & $40^{\circ} \mathrm{C}, 2 \mathrm{~h}$ & $79.6 \pm 4.1$ & $95.0 \pm 5.1$ \\
Females & $45^{\circ} \mathrm{C}, 1 \mathrm{~h}$ & $69.0 \pm 2.4$ & $88.8 \pm 5.8$ \\
Females & $40^{\circ} \mathrm{C}, 2 \mathrm{~h} / 45^{\circ} \mathrm{C}, 1 \mathrm{~h}$ & $74.7 \pm 3.2$ & $89.0 \pm 7.4$ \\
Females & $40^{\circ} \mathrm{C}, 2 \mathrm{~h} / 25^{\circ} \mathrm{C}, 4 \mathrm{~h} / 45^{\circ} \mathrm{C}, 1 \mathrm{~h}$ & $74.9 \pm 2.4$ & $91.9 \pm 9.6$ \\
\hline
\end{tabular}


negatively affected fecundity, and all were partially or fully protected by the induction of rapid cold hardening.

The failure of adult eclosion was noted previously in $S$. crassipalpis (Lee \& Denlinger, 1985). Additional mortality was realized in the form of decreased adult longevity; $20 \%$ of the cold-shocked flies survived 10 days post-emergence, whereas $85 \%$ of the untreated controls survived. This decrease in adult longevity is similar to that seen as a result of both chronic and acute cold stress in other species of Diptera (Coulson \& Bale, 1992; Jones \& Kunz, 1998). Both of these reductions in survival lead to a reduction in the reproductive potential of the affected flies. The induction of rapid cold hardening increased adult longevity dramatically, much as it did in preventing the reduction in eclosion behaviour (Chen et al., 1987; Lee et al., 1987). Hence, rapid cold hardening protected the fecundity potential of cold-shocked animals to near normal levels with respect to premature death.

Surviving flies also exhibited a reduction in fecundity, in the form of decreased egg fertilization. This was most dramatic when both sexes were treated, but the cold shock of either sex alone caused significant decreases as well, demonstrating that both sexes sustained injury. Cold shock can cause damage to diverse tissues in a developing insect, many of which could lead to impairment of reproductive abilities. Delayed development of the ovaries has been previously reported (Jones \& Kunz, 1998), as has the development of wing deformities (Hegdekar, 1971), muscle degeneration and impaired nervous function (Yocum et al., 1994; Kelty et al., 1996). Although the retention of egg production in our flies suggests that ovarian development was not affected, many other detrimental effects did manifest themselves, including wing deformities and decreased ability to fly (unpublished observations). A combination of these effects could give rise to the observed decrease in mating incidence, leading to a decrease in resultant fecundity.

Similar to decreased longevity, the decrease in egg fertilization was ameliorated by rapid cold hardening. Protection was complete when either sex was pre-treated independently, but pre-treatment of both sexes resulted in only partial amelioration. Concurrent with this protection was a resumption of normal levels of mating behaviour and the absence of physical defects.

Our data suggest that rapid cold hardening may play a significant role in the protection of the reproductive fitness of a naturally occurring population of flies. Although the laboratory

Table 5. The impact of different durations of a $45^{\circ} \mathrm{C}$ heat shock on fecundity when administered to both males and females during pharate adult development. $n=15$ females per treatment group.

\begin{tabular}{lll}
\hline $\begin{array}{l}\text { Duration of } \\
45^{\circ} \mathrm{C} \text { treament }(\mathrm{min})\end{array}$ & $\begin{array}{l}\text { No. eggs produced } \\
\text { Mean } \pm \mathrm{SE}\end{array}$ & $\begin{array}{l}\text { Percentage fertilized } \\
\text { Mean } \pm \mathrm{SE}\end{array}$ \\
\hline 0 & $77.7 \pm 1.9$ & $91.2 \pm 2.6$ \\
15 & $84.8 \pm 4.2$ & $78.5 \pm 6.9$ \\
30 & $80.0 \pm 3.5$ & $0.0 \pm 0.0$ \\
45 & $80.4 \pm 2.4$ & $0.0 \pm 0.0$ \\
60 & $70.3 \pm 2.2$ & $0.0 \pm 0.0$ \\
\hline
\end{tabular}

conditions included dramatic changes in temperature that are rarely observed in ecological situations, the data suggest that flies that experience moderately low temperatures are capable of inducing physiological changes that not only protect against death, but also against temperature-induced reductions in fecundity.

The effect of high temperature exposure on reproductive success differed considerably from that of low temperature, with a reduction in both egg production and egg fertilization being realized. Of additional interest, heat shock of individual sexes led to different effects: treatment of only the males resulted in sterility, whereas the treatment of females resulted in reduced egg production without significantly affecting the proportion of eggs that were fertilized.

The reduction of male fertility by heat shock is consistent with studies in the parasitic wasp Trichogramma brassicae (Chihrane \& Lauge, 1994) and D. melanogaster (Krebs \& Loeschcke, 1994). Sterilization is most likely due to direct injury to the testes and sperm of the fly, especially considering that the later life stages, concurrent with the later stages of sperm development, are most affected by heat shock. Previous studies in Hymenoptera have shown that a similar heat regime affects male germ lines, leading to the production of atypical sperm or empty seminal vesicles (Chihrane \& Lauge, 1997). In S. crassipalpis, the absence of fertilized embryos in females mated with heat-shocked males is consistent with male sterility, as is the absence of sperm in the spermatheca.

The effect of heat shock on female fecundity is also consistent with the aforementioned models, and is likely due to direct injury to developing oocytes. Female germ lines of Hymenoptera sustain thermal damage manifested as abnormally formed ovaries, or as ovaries that remain in their juvenile state (Chihrane \& Lauge, 1997). Impairment of ovarian development could lead to the decrease in egg production that we observed. Induced thermotolerance led to a partial protection of female fecundity, whereas males were unable to generate such protection. Interestingly, the induction of thermotolerance in both sexes, a more ecologically relevant scenario, had no effect on egg fertilization, even though egg production was partially preserved. This differs greatly from rapid cold hardening, which protected both sexes from the effects of cold shock, and therefore could be expected to afford protection to a naturally occurring population.

The inability of males to acquire thermotolerance against sterility is in agreement with D. melanogaster studies (Krebs \&

Table 6. Differences in the impact of a 30-min heat shock at $45^{\circ} \mathrm{C}$ when administered to both males and females at different developmental stages. $n=45$ females per treatment group.

\begin{tabular}{lll}
\hline Stage heat shocked & $\begin{array}{l}\text { No. eggs produced } \\
\text { Mean } \pm \text { SE }\end{array}$ & $\begin{array}{l}\text { Percentage fertilized } \\
\text { Mean } \pm \text { SE }\end{array}$ \\
\hline Untreated & $78.7 \pm 3.7$ & $93.4 \pm 4.7$ \\
Wandering larvae & $80.0 \pm 1.6$ & $93.1 \pm 5.8$ \\
Pupa & $79.8 \pm 4.4$ & $85.5 \pm 8.7$ \\
Pharate adults & $78.1 \pm 3.9$ & $1.3 \pm 0.0$ \\
Adults & $74.3 \pm 2.5$ & $1.3 \pm 0.0$ \\
\hline
\end{tabular}


Table 7. Reduction in sperm present in the spermatheca of 10-dayold adult females when mated with males that had been heat shocked $\left(45^{\circ} \mathrm{C}\right)$ during pharate adult development. $n=9$ females per treatment group.

\begin{tabular}{lc}
\hline $\begin{array}{l}\text { Temperature } \\
\text { treatment }\end{array}$ & $\begin{array}{l}\text { No. of sperm collected } \\
\text { Mean } \pm \text { SE }\end{array}$ \\
\hline $25^{\circ} \mathrm{C}$ & $1498.3 \pm 344.0$ \\
$40^{\circ} \mathrm{C}, 2 \mathrm{~h}$ & $1570.0 \pm 488.0$ \\
$45^{\circ} \mathrm{C}, 1 \mathrm{~h}$ & $4.2 \pm 1.9$ \\
$40^{\circ} \mathrm{C}, 2 \mathrm{~h} / 45^{\circ} \mathrm{C}, 1 \mathrm{~h}$ & $8.3 \pm 3.5$ \\
\hline
\end{tabular}

Loeschcke, 1994), although T. brassicae males have such an ability (Maisonhaute et al., 1999). This lack of protection may be the consequence of the tissues affected. A significant element in the response to temperature extremes is the upregulation of heat shock proteins (Feder \& Hofmann, 1999), a group of proteins that are upregulated by environmental stress as well as during specific periods of development. Although thermotolerance is sometimes manifested in the absence of these proteins (Yocum \& Denlinger, 1992; Dahlgaard et al., 1998), they are clearly upregulated at $40^{\circ} \mathrm{C}$ in $S$. crassipalpis (Yocum et al., 1998; Rinehart et al., 2000) and their presence can lead to protection from thermal injury (Feder \& Hoffman, 1999). However, their function during stress in the testes appears to be altered because some heat shock proteins are expressed as a function of normal spermatogenesis; hsp70 is involved in mammalian models (Eddy, 1999), and members of the small heat shock protein family are involved in developing testes of $D$. melanogaster (Michaud et al., 1997). This developmental regulation of expression patterns can lead to the suppression of their upregulation by heat shock (Michaud et al., 1997), and if this response is not suppressed, it can be directly linked to thermal testicular damage (Sarge \& Cullen, 1997). Hence, the role of heat shock proteins is altered during spermatogenesis, and this change may be partially responsible for the lack of thermoprotection of these tissues.

Although oogenesis involves the developmental regulation of heat shock proteins as well (Zimmerman et al., 1983), thermoprotection of the ovaries did occur, with pre-treatment leading to the partial restoration of female fecundity in this and other species (Krebs \& Loeschcke, 1994; Maisonhaute et al., 1999). Of additional interest, induced thermotolerance lasts for at least $4 \mathrm{~h}$, whereas hsp23 and hsp70 expression lasts for only $2 \mathrm{~h}$ after such a treatment (Yocum et al., 1998; Rinehart et al., 2000), suggesting that other mechanisms may be involved in thermotolerance, as has been previously suggested (Yocum \& Denlinger, 1992).

The ecological significance of thermotolerance with respect to fecundity remains unclear. Although the induction of thermotolerance does lead to greater survivorship to adulthood (Yocum \& Denlinger, 1992), which would thereby increase the reproductive potential of a naturally occurring population, the problem of male sterility would still be encountered. It would therefore be counterintuitive to develop a system of induced thermotolerance that does not protect the gonads from injury. How this problem may be averted still needs investigation.

\section{Acknowledgements}

The authors thank Tade Adedokun for his technical assistance with the early phase of this project. This work was funded in part by NSF-IBN grant no. 9728573 .

\section{References}

Arbogast, R.T. (1981) Mortality and reproduction of Ephestia cautella and Plodia interpunctella exposed as pupae to high temperatures. Environmental Entomology, 10, 708-710.

Armstrong, J.W. (1992) Fruit fly disinfestations strategies beyond methyl bromide. New Zealand Journal of Crop Science and Horticultural Science, 20, 181-193.

Bale, J.S., Hansen, T.N., Nishino, M. \& Baust, J.G. (1989) Effects of cooling rate on the survival of larvae, pupariation, and adult emergence of the gallfly Eurosta solidaginis. Cryobiology, 26, 285289.

Chen, C.P., Lee, R.E. \& Denlinger, D.L. (1987) Cold-shock injury and rapid cold hardening in the flesh fly Sarcophaga crassipalpis. Physiological Zoology, 60, 297-304.

Chen, C.P., Lee, R.E. \& Denlinger, D.L. (1991) Cold shock and heat shock: a comparison of the protection generated by brief pretreatment at less severe temperatures. Physiological Entomology, 16, 19-26.

Chihrane, J. \& Lauge, G. (1994) Effects of high-temperature shocks on male germinal cells of Trichogramma brassicae (Hymenoptera, Trichogrammatidae). Entomophaga, 39, 11-20.

Chihrane, J. \& Lauge, G. (1997) Thermosensitivity of germ lines of Trichogramma brassicae Bezdenko (Hymenoptera). Implications for efficacy of the parasitoid. Canadian Journal of Zoology, 75, 484-489.

Chihrane, J., Lauge, G. \& Hawlitzky, N. (1993) Effects of hightemperature shocks on the development and biology of Trichogramma brassicae (Hymenoptera, Trichogrammatidae). Entomophaga, 38, 185-192.

Coulson, S.C. \& Bale, J.S. (1992) Effect of rapid cold hardening on reproduction and survival of offspring in the housefly Musca domestica. Journal of Insect Physiology, 38, 421-424.

Dahlgaard, J., Loeschcke, V., Michalak, P. \& Justesen, J. (1998) Induced thermotolerance and associated expression of the heatshock protein Hsp70 in adult Drosophila melanogaster. Functional Ecology, 12, 786-793.

Denlinger, D.L., Joplin, K.H., Chen, C.-P. \& Lee, R.E. (1991) Cold shock and heat shock. Insects at Low Temperature (ed. by R. E. Lee and D. L. Denlinger), pp. 131-148. Chapman \& Hall, New York.

Denlinger, D.L. \& Lee, R.E. Jr (1998) Physiology of cold sensitivity. Temperature Sensitivity in Insects and Application in Integrated Pest Management (ed. by G. J. Hallman and D. L. Denlinger), pp. 55-97. Westview Press, Boulder, CO.

Denlinger, D.L. \& Yocum, G.D. (1998) Physiology of heat sensitivity. Temperature Sensitivity in Insects and Application in Integrated Pest Management (ed. by G. J. Hallman and D. L. Denlinger), pp. 7-54. Westview Press, Boulder, CO.

Eddy, E.M. (1999) Role of heat shock protein hsp70-2 in spermatogenesis. Reviews of Reproduction, 4, 23-30.

Feder, M.E. \& Hofmann, G.E. (1999) Heat-shock proteins, molecular chaperones, and the stress response. Annual Review in Physiology, 61, 243-482.

Hansen, J.D. (1992) Heating curve models of quarantine treatments 
against insect pests. Journal of Economic Entomology, 85, 18461854.

Hegdekar, B.M. (1971) Wing aberrations induced by precooling pharate adults of the fly Pseudosarcophaga affinis. Canadian Journal of Zoology, 49, 952.

Jones, S.R. \& Kunz, S.E. (1998) Effects of cold stress on survival and reproduction of Haematobia irritans (Diptera: Muscidae). Journal of Medical Entomology, 35, 725-731.

Kelty, J.D., Killian, K.A. \& Lee, R.E. (1996) Cold shock and rapid cold-hardening of pharate adult flesh flies (Sarcophaga crassipalpis): effects on behaviour and neuromuscular function following eclosion. Physiological Entomology, 21, 283-288.

Krebs, R.A. \& Loeschcke, V. (1994) Effects of exposure to short-term heat-stress on fitness components in Drosophila melanogaster. Journal of Evolutionary Biology, 7, 39-49.

Lee, R.E., Chen, C.-P. \& Denlinger, D.L. (1987) A rapid cold hardening process in insects. Science, 238, 1415-1417.

Lee, R.E. \& Denlinger, D.L. (1985) Cold Tolerance in diapausing and non-diapausing stages of the flesh fly, Sarcophaga crassipalpis. Physiological Entomology, 10, 309-315.

Maisonhaute, C., Chihrane, J. \& Lauge, G. (1999) Induction of thermotolerance in Trichogramma brassicae (Hymenoptera: Trichogrammatidae). Environmental Entomology, 28, 116-122.

Michaud, S., Marin, R., Westwood, J.T. \& Tanguay, R.M. (1997) Cellspecific expression and heat-shock induction of hsps during spermatogenesis in Drosophila melanogaster. Journal of Cell Science, 110, 1989-97.

Milkman, R. (1962) Temperature effects on day-old Drosophila development. Journal of Insect Physiology, 45, 777-799.
Mitchell, H.K. \& Lipps, L.S. (1978) Heat shock and phenocopy induction in Drosophila. Cell, 15, 907-918.

Rinehart, J.P., Yocum, G.D. \& Denlinger, D.L. (2000) Developmental upregulation of inducible hsp70 transcripts, but not the cognate form, during pupa diapause in the flesh fly, Sarcophaga crassipalpis. Insect Biochemistry and Molecular Biology, 30, 515-521.

Sarge, K.D. \& Cullen, K.E. (1997) Regulation of hsp expression during rodent spermatogenesis. Cellular and Molecular Life Sciences, 53, 191-197.

Saxena, B.P., Sharma, P.R., Thappa, R.K. \& Tikku, K. (1992) Temperature induced sterilization for control of three stored grain beetles. Journal of Stored Product Research, 28, 67-70.

Yocum, G.D. \& Denlinger, D.L. (1992) Prolonged thermotolerance in the flesh fly, Sarcophaga crassipalpis, does not require continuous expression or persistence of the $72 \mathrm{kDa}$ heat-shock protein. Journal of Insect Physiology, 38, 603-609.

Yocum, G.D., Joplin, K.H. \& Denlinger, D.L. (1998) Upregulation of a $23 \mathrm{kDa}$ small heat shock protein transcript during pupal diapause in the flesh fly, Sarcophaga crassipalpis. Insect Biochemistry and Molecular Biology, 28, 677-682.

Yocum, G.D., Zdarek, J., Joplin, K.H., Lee, R.E. Jr, Smith, D.C., Manter, K.D. \& Denlinger, D.L. (1994) Alteration of the eclosion rhythm and eclosion behaviour in the flesh fly, Sarcophaga crassipalpis, by low and high temperature stress. Journal of Insect Physiology, 40, 13-21.

Zimmerman, J.L., Petri, W. \& Meselson, M. (1983) Accumulation of a specific subset of D. melanogaster heat shock mRNAs in normal development without heat shock. Cell, 32, 1161-1170.

Accepted 17 August 2000 